\title{
Hawaiian Outrigger Canoes of the Bonin Archipelago
}

\author{
SCOTT KRAMER AND
}

HANAE KURIHARA KRAMER

In THE NINETEENTH CENTURY, immigrants from many lands came to Hawai'i and left their mark upon the islands. Equally relevant but less known are the stories of Native Hawaiians who carried their culture to foreign shores. One such group of pioneers settled the uninhabited Bonin Archipelago (Ogasawara Islands) in 1830, where they transplanted Hawaiian customs, language, and technology. Their island colony, situated in the remote waters of the western Pacific, roughly midway between Japan and the Marianas, became a well-known stop for whalers seeking fresh supplies as well as respite from the sea. The comings and goings of people over the years affected the Bonin colony's makeup as did Japanese occupation in 1875 . Despite the dramatic political and demographic changes that befell the archipelago in the late nineteenth century, some of its Hawaiian roots endure. The most manifest example is perhaps the single-hulled outrigger canoe, or wa'a kaukahi. ${ }^{1}$ Early twentieth-century postcards and travel literature made it an unofficial symbol of the Bonin Archipelago. In addition to being a source of inspiration for writers, it was a common prop for photographers and a frequent subject for artists. The out-

Scott Kramer received his master's degree in Japanese history from the University of Hawai 'i. Hanae Kurihara Kramer is an assistant professor at the School of Communications on the Mānoa campus, where she teaches intercultural and global communication.

The Hawaiian Journal of History, vol. 49 (2015) 
rigger canoe enjoyed widespread use well past the conclusion of the Second World War. Even today it can be seen near water's edge, 185 years after the first Hawaiians arrived.

Craftsmen in the Hawaiian chain produced a wide variety of double and single-hulled canoes. The Bonin islanders limited their efforts to single-hulled dugouts supported upright by one lateral float held in place by two booms. The islanders largely dispensed with ceremonial aspects of canoe making. A small population with limited needs resulted in vessels of relatively uniform design. The colony was originally comprised of a few dozen Hawaiians and five Caucasian males who had experience with Polynesian cultures before relocating to the Bonins. ${ }^{2}$ According to the historian Yamagata Ishinosuke, a Dane named Charles Johnson introduced the outrigger canoe. ${ }^{3}$ Johnson was probably an early maker of Hawaiian-style canoes, but it is far from certain that he was the first. What is certain is that local Caucasians were as enthusiastic about the technology as the Hawaiians. Japanese who moved to the archipelago in the late nineteenth century following colonization embraced the Hawaiian watercraft like their neighbors. Boat builders from Japan's Hachijō island began making outrigger canoes after spending time in the Bonins. These men even introduced the technology to their families and friends back home, where fishing boats today are still fitted with outriggers to produce an unusual looking construction. ${ }^{4}$ Canoes in the Bonin Archipelago incorporated Western and Japanese elements, more so over the course of time. Coastal deforestation, access to more materials, and modern techniques eventually made traditional dugouts obsolete, but the Bonin outrigger canoe kept its form and function.

\section{Construction \& Design}

In 1888 , a visitor to the Bonins briefly described how islanders made their canoes. During the summer months, men felled large trees that were then shaved down and carved out. That is, each tree trunk was stripped of its branches and debarked before being hollowed by repetitive ax strikes. The next step was to haul these rough-hewn canoes into shaded areas, where the wood was allowed to cure in ideal conditions for many weeks or months. Commonly used in home construction, the endemic $a k \bar{o}$ (a member of the citrus family) was preferred 


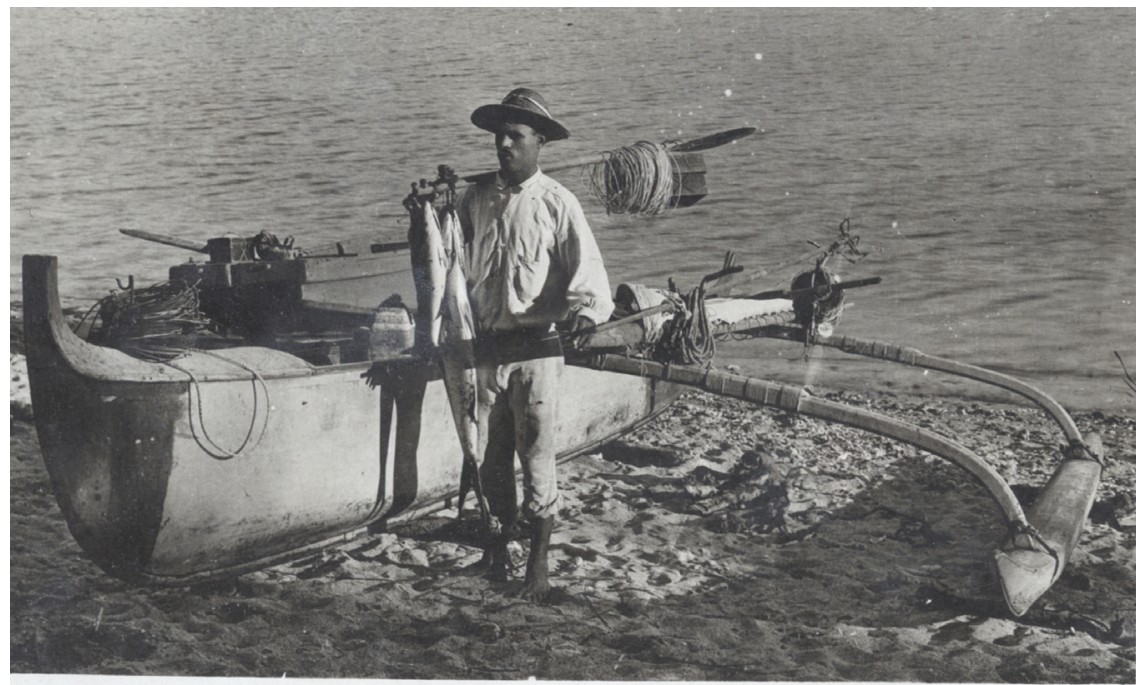

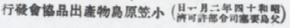

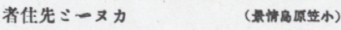
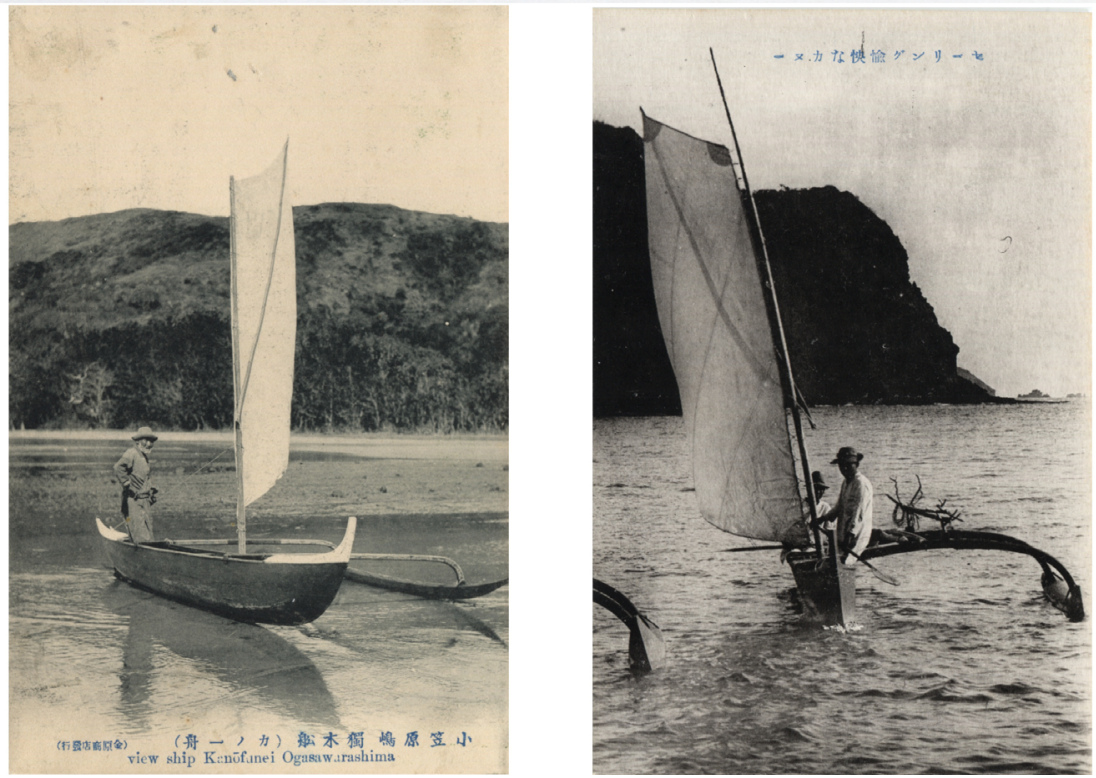

FIGURE 1. The above three postcards were in circulation during the interwar period (1918-1939). Courtesy of Ogasawara Village's Board of Education. 
because of its buoyancy and strength, as were the pan-Pacific species sendan (chinaberry) and hasunohagiri (jack-in-the-box). Following the drying process, each canoe was hewn, chiseled, and carved into its signature shape. Two arched booms, or cross beams, attached a lateral support float to the hull. Cords held everything together. Canoe makers chose pieces of naturally bowed wood for the booms, often from the ichibi, a large hibiscus endemic to the Bonins that was used for making paddles and masts as well. Wood covers capped both ends of the hull. The empty spaces underneath these covers found function as storage areas. Outrigger floats were one fifth the size of the hull and similarly shaped. Western-style cotton sails accompanied canoes that had masts. When logs of sufficient girth could not be obtained islanders raised the sides of their canoes with gunwales or washstrakes, tightly fitted boards of cedar or cypress that prevented water from spilling into shallow hulls. ${ }^{5}$ It was also said that some canoe makers applied coal tar to surfaces with the intent of preserving the wood. ${ }^{6}$

In 1840 , local dugouts measured roughly nine feet long by two and a half feet wide, according to a group of Japanese castaways who washed up in the Bonin Archipelago. ${ }^{7}$ Forty-eight years later, widths had not changed all that much. If anything they had become more narrow but lengths now, in 1888 , ranged from ten to twenty feet; the average hull depth was approximately one and one half feet. ${ }^{8}$ Floats varied in size. A sketch of a Bonin canoe from the 184 os suggests that floats were one third the length of hulls. ${ }^{9}$ This is greater than the 1888 account that reported floats to be only one fifth. Sources from other periods give yet different proportions. Islanders also constructed halfsized outrigger canoes that women took out by themselves. These petite watercraft measured about four feet in length by one and a half to two feet in width. ${ }^{10}$

Little about the construction and design of the Bonin canoe was recorded for posterity's sake, despite it being an island fixture. Three factors are largely responsible. First and foremost, the islanders did not document many aspects of their daily lives: a fact that historians bemoan. Second, the Bonin Archipelago is remote geographically and otherwise. In years past this discouraged scholarly excursions there. Even today, visitors must endure a twenty-five hour ship ride that departs from Tokyo only once every five or six days to reach the archipelago's principal anchorage at Port Lloyd (Futami-kō).${ }^{11}$ Third, 


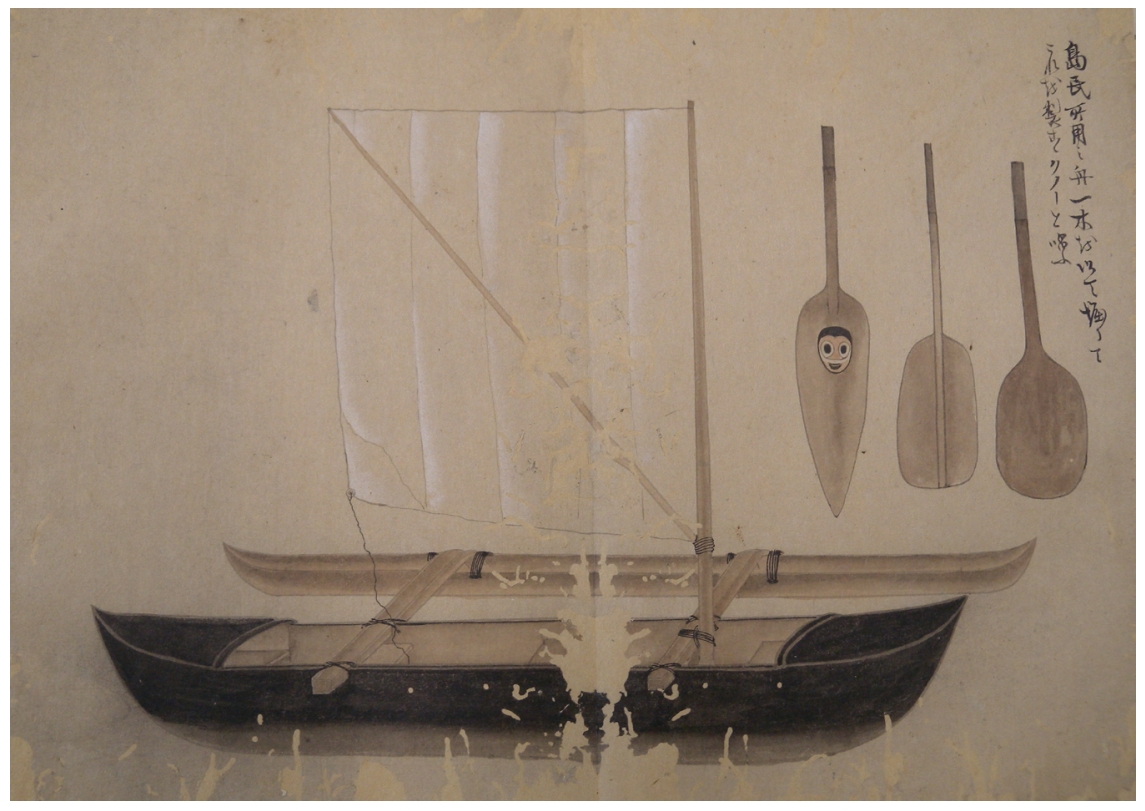

Figure 2. This late nineteenth century rendition of a Bonin canoe comes from Obana Sakusuke's Ogasawaratō zue (pictures of the Ogasawara Islands). Courtesy of Ogasawara Village's Board of Education.

military men did their best to curtain off the Bonin Archipelago from the rest of the world. In the 193os, the Japanese restricted access to the islands in an attempt to keep their activities there a secret. Foreign visitors were no longer welcome, and information coming out of the Bonins underwent heavy scrutiny by censors. ${ }^{12}$ During the height of the Cold War, an article in the Chicago Tribune claimed that the United States Navy attempted in the Bonins "to set up its own little empire under the pretext of maintaining a base vital to free world security." ${ }^{13}$ The American navy isolated the islands and its inhabitants even more thoroughly than the Japanese had done. Journalists, scholars, and just about everyone else unconnected to the naval facility were refused entry until the late $1960 \mathrm{os} .{ }^{14}$ Given this history of prolonged sequestration, it should surprise no one to learn that the most authoritative source on the Bonin canoe in the English languageperhaps any language-is based upon the study of a model. 


\section{Wooden Model of a Bonin Canoe}

Japan's Bureau of Fisheries in 1910 gifted London's Science Museum a small-scale replica of a Bonin canoe. ${ }^{15}$ A mere novelty when presented, the model has since become an important historical artifact because of the dearth of extant materials. James Hornell studied it when researching his 1936 book Canoes of Oceania. He concluded that "the design of both hull and outrigger approximates so closely to the Hawaiian that if the history of the colonization of the [Bonin] islands were not known various erroneous theories might be founded on this fact." ${ }^{16}$ Due to the specificity of Hornell's description of the model, paraphrasing his words would be a poor substitute to providing the original text:

The hull of the canoe [see figure 3] is a double-ended dugout. The ends are almost identical, curved, sharp, and capped above by short and pointed triangular end pieces sharply curved upward; weatherly qualities are given by a short, slightly arched deck at each end, butting against the after side of the small end piece. These canoes run to 30 feet in length, according to the information which accompanies the model.

The outrigger consists of two similarly shaped booms curving downward in their distal part to their insertion into the float at a distance outboard of about 8 feet. The pointed end of each is forced into a hole made in the ridged midline of the float and is further secured by a collar lashing to a peg inserted on the inner aspect of the float [inset a].

The proximal ends of the booms lie athwart the dugout hull and rest upon the gunwales. Crossing the hull a short distance immediately below each boom is a convexly bowed wooden thwart bar or boom brace; its ends pass through the sides and show on the outside a couple of inches below the gunwale. To this the inboard part of the boom is secured by two collar lashings [inset b]. A method of attachment of the same type is found in the South Celebes and in a varietal form is general throughout Indonesia.

The float is two-fifths of the length of the hull. The ends are pointed and the upper surface is ridged longitudinally; the sides and bottom are rounded as in the dugout hull. A curious feature is its compound construction; it consists of a basal part hollowed out in canoe fashion, and an upper part made of a long board broadly triangular in transverse section, fitting over the hollowed under part like the ridged cover 
of a sarcophagus. In the model the cover is glued on; whether the float is bipartite in full-sized canoes is not known.

A mast rigged with a half spritsail is stepped in the bottom immediately abaft the fore boom, to which it is strongly lashed. ${ }^{17}$

The particulars in the above-cited text point to a canoe of Hawaiian origin with elements borrowed from other maritime traditions, namely European and Japanese. James Hornell thought that the model's boom lashings suggested an Indonesian influence as well, which is plausible given the history of cultural exchange in the Bonin Archipelago. ${ }^{18}$ The lashings, however, might just be the result of the model's craftsman deviating from the canoe's original design for expediency's sake, or due to the challenges of working in a smaller

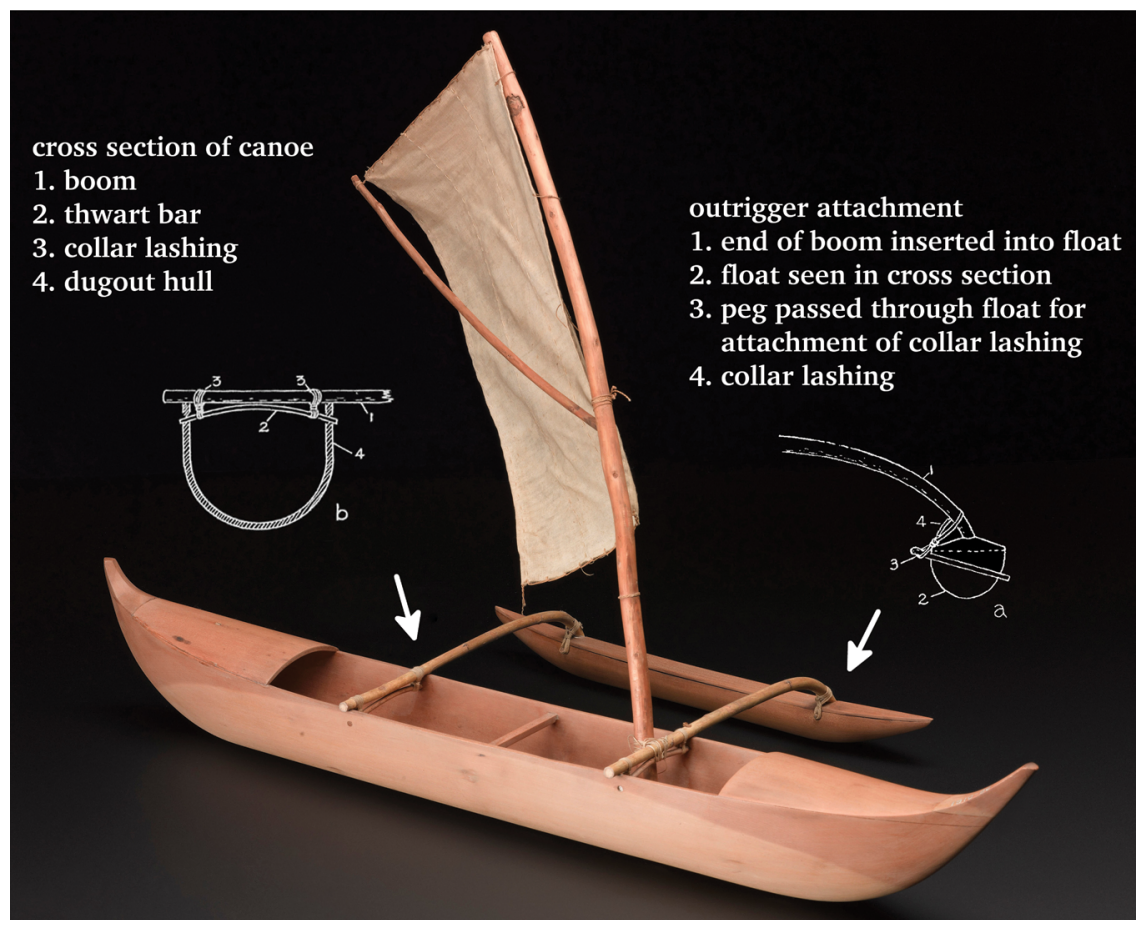

FIGURE 3. This wooden model measures approximately 26 inches high $\times 10^{1 / 2}$ inches wide $\times 20$ inches deep. As is typical with Hawaiian canoes the float is located on the port side. Photograph and measurements courtesy of The Science Museum. Insets courtesy of the Bernice P. Bishop Museum. 
scale. Hornell's determination to describe the model in detail is readily apparent. The issue at hand is not his competency as a scholar, but whether or not the model was an accurate representation of a Bonin canoe at the turn of the last century.

Photographs and drawings confirm that the model's hull, float, sail, booms, and other pronounced features are consistent with canoes of the period. The model's smaller, more intricate parts are where one would expect craftsmen to take liberties. And it is these very parts (pegs, some lashings, et cetera) that escaped the artist's hand and photographer's eye. There is one notable exception, however. Period visuals show float collar lashings unlike those found on the model: cords used to secure the distal part of a boom are present on both sides of the float, not merely confined to "the inner aspect" as is the case with the Science Museum's model. Additionally, some photographs clearly show booms with pegs or bolts sticking out of them that are used to support the collar lashings. ${ }^{19}$ The model should be viewed with a degree of skepticism when it comes to its complete authenticity, but this in no way diminishes its value as a historical artifact. After all, the model may have merely replicated in miniature a less common float design.

If conclusions may be drawn from a comparison of the 1888 account and Hornell's 1936 study of the Science Museum's model with its accompanying text, then it can be said that over time floats grew in proportion to hull sizes, and that the grandest of hulls became a third longer (from twenty feet to thirty). This was the continuation of a ongoing trend. Islanders constructed ever longer hulls during the settlement's first 1 oo years. In 1840, as stated earlier, canoes only measured about nine feet from tip to tail. Extreme builds aside, though, photographic evidence from the period suggests that the average canoe length did not change much within the near halfcentury between 1888 and 1936 . The islanders by accounts seemed content with their basic two- and three-person canoes, which they pushed through the water with traditional paddles and sculling oars.

\section{Canoe Masks}

A Japanese expedition to the Bonin Archipelago in the early 1860 s observed that ornate masks adorned local canoes, and that paddle 
blades had a human face painted on them or, at least, what looked to be a human face (see figure 2).$^{20}$ These cultural artifacts are alien to the Hawaiian, Japanese, and European traditions. There is no evidence to advance the argument that they are indigenous creations either. Two contemporary scholars believe the masks to have been talismans of Melanesian origin, with one-Professor Gotō Akirafurther localizing his speculation to New Ireland in the Bismarck Archipelago. ${ }^{21}$ The artwork on the paddle blades is reminiscent of ceremonial paddles on Bougainville Island, also located in Melanesia. ${ }^{22}$ The expedition's report Ogasawaratō shinkeizu (landscapes and scenes of the Ogasawara Islands) provided drawings but not much in the way of commentary. The hows and whys, therefore, have been lost to time. Had a sojourner (Melanesian or otherwise) brought the customs to the archipelago? Did a Bonin islander pick them up during his or her travels? Was this proof of an immigrant holding onto his native traditions? We will probably never know. What is clear is that the practice of adorning canoes with masks and paddle blades with painted faces was not long lived, and may not have even been widespread either. No original pieces have survived to be studied. The above mentioned Japanese expedition purchased from the islanders three canoes and gear, the fate of which remain unknown..$^{23}$ Today, a less than exact replica mask hangs on the wall of a quasi-government building in the archipelago's principal town. ${ }^{24}$

\section{Five Stories in Five Paragraphs}

With its speed and maneuverability, strong paddlers could reach most of the archipelago's islands in a day or two. Wind-filled sails permitted even faster travel. Although the Bonin islanders were able canoeists, risk was always present when they entered the ocean. A man described in Japanese texts as "the Kanaka named Furaidē [Friday] Topoto" and one of the descendants of William Gilley, an Occidental who is best remembered for being murdered, crossed the watery divide that separated the islands of Chichijima and Hahajima in the late 1870 so buy a new canoe. ${ }^{25}$ On their return trip, each man set out by himself. Gilley made it back without incident, but Friday, in the new canoe, was lost at sea. This was not an uncommon occurrence. In fact, a canoe maker named "Tomu Chukurabu [Tom or Thomas Two-Crabs]" was 
swept from his course that very same day. Tom-along with his wife, two children, and a female companion-remained stranded on an uninhabited outer island for a week and a half until being rescued. ${ }^{26}$ Visitors had no immunities from the dangers either. William Hall of New Jersey, in April of 1857 , "drowned by the upsetting of a canoe along side of the whale ship 'Mt. Vernon'." ${ }^{27}$ Jenichiro Oyabe, an eccentric who fancied himself a Japanese Robinson Crusoe, at a date anterior to 1898 , fell victim to the sea and his own ignorance when he borrowed a canoe without permission for an unsupervised joy ride. He almost lost his life that day, but at least he was able to turn his misadventure into a short book chapter for the reading public's entertainment. ${ }^{28}$

Canoes are woven into the fabric of Bonin history, so they appear in heartwarming narratives as well as unsavory tales of murder and deceit. The disappearance of Benjamin Pease and subsequent events highlight man's darker nature, and the role canoes played in local misdeeds. Pease was last seen alive on the morning of October 9, 1874 , when he left his home to visit a neighbor who lived about $2^{1 / 2}$ miles away by water. Pease never reached the residence of Thomas Webb. Two days after he went missing, his damaged canoe was found bottom up close to the rocks. Locals had little doubt that Pease met with foul play. Suspicion immediately fell upon Spenser, a dark-skinned man who had come to the Bonins from Ascension Island (Pohnpei) a year or so prior. Spenser had lived with Pease until the latter suspected the former of having a romantic liaison with his wife. A quarrel turned into threats of violence. Amid escalating tensions Pease failed to return home. Island life appeared to return to normal sometime after that, but eight months later, on June 11, 1875, Spenser himself vanished under circumstances as inexplicable as those in connection with his rival. Using a borrowed canoe from Robert Myers, Spenser set out from Webb's residence looking for turtles to catch. The canoe was found two days later splashed with blood. Spenser's bloodstained coat was torn across the back, apparently with a turtle hook. He, too, was never seen again. Russell Robertson, the British consul at Kanagawa, tried to investigate the matter when he visited the Bonins in 1875 . Robertson wrote the following in his report:

I questioned Pease's widow in respect to his disappearance, but all my questions were answered by monosyllables, accompanied by a silly laugh. The woman had a baby at her breast, born but a few weeks prior 
to our visit, and of which, judged by the date of Pease's disappearance, he cannot have been the father. It is currently reported on the island that Spenser was the father of the child. ${ }^{29}$

The canoe in which Spenser was killed, according to its owner Robert Myers, was involved in another incident. Several months earlier, members of the Two-Crabs family unsuccessfully chased after the canoe's unnamed occupant with intent to cause harm. ${ }^{30}$ Canoes occupied daily life in the Bonins, even the seamy side.

The waters surrounding the Bonins are full of sharks. In the nineteenth century, European and American visitors reported that these predators attacked their boats with great voracity. ${ }^{31}$ Since most sharks in the archipelago are relatively small, the danger posed to safetyconscious sailors is minimal. However, large sharks have on occasion endeavored to eat local fishermen. The following was published in 1917 :

When fishermen enter the sea, sharks notice because canoes cast shadows. It is quite common for sharks to gather and circle around canoes in anticipation of tasting human flesh. Several years ago, a fisherman from Hahajima was attacked. Without warning, a huge shark rose its head out of the water and wrapped its jaws halfway around the fisherman's canoe. He dropped his body into the hull, narrowly escaping the shark's teeth. The canoe was shaken violently but stayed intact, fortunately. A later inspection of the craft found three big teeth stuck in the hull's wooden bottom. ${ }^{32}$

In the Bonin Archipelago, outrigger canoes had a role in sport, leisure, and even romance. There was a time when a man's marital appeal was determined by his ability to catch turtles, which required skilled paddling. ${ }^{33}$ With the growing importance of local agriculture and trade, this was less true in the twentieth-century. Nevertheless, the canoe was still on occasion a vehicle for romance. Sometime before 1917 , a young man from Japan proper, who fancied himself a writer, and a mixed-race local beauty sought privacy on the water to share each others' company. A jealous teenage boy attempted to ruin the couple's plans by deliberately damaging their canoe. When the hull began to leak, the young mainlander jumped into the water naked to pull the canoe ashore so his companion's clothes would not get wet. The couple set out again after plugging the hole, but the young man's 
poor boatmanship forced the girl to do most of the day's paddling. This canoe courtship met with an unsuccessful ending, for although the girl was smitten by the young man's charms, he stopped pursuing her affections.

Outrigger canoes during the First World War (1914-1918) numbered 139, up from 61 in the late 189 os according to reports. ${ }^{34}$ Regardless of how complete these numbers are, they aptly demonstrate the pervasiveness of the canoe given the small population of the Bonin Archipelago. The local government office (Ogasawaratō tōchō) maintained five canoes in 1908, while the post office owned three, and the police department kept one on hand. ${ }^{35}$ Local authorities used canoes for emergencies, supervising waterways, monitoring the coastline, protecting turtles from poachers, ceremonial farewells, and other state related functions. ${ }^{36}$ In short, the canoe was an asset to public servants just like it was for all people living in the Bonin Archipelago. Perhaps the most significant official event was the stay of Emperor Hirohito, who visited the Bonins in 1927 to inspect his empire's most remote outpost. Had the importance of the outrigger canoe in local culture not been known to the imperial entourage before their arrival, then this fact became evident to them during their stay. Canoes, talk of canoes, and canoe-inspired artistic expression were ever-present. School children's projects presented to the emperor did not deviate from the pattern. It was a technology and a symbol of island life that was inescapable. Even specialists employed by the imperial household relied on canoes to collect specimens for Hirohito's private biology collection. When His Majesty departed Port Lloyd on July 31, 1927, his ship was flanked by fifty or more canoes with flags in a patriotic display never before or since seen on the islands. The ship was carried out to sea on waves of banzais (shouts of "long live the emperor"). ${ }^{37}$ This visit appears to have had a lasting impression upon the young Hirohito, for later in life he authored the book Some Hydrozoans of the Bonin Islands, published by the Imperial Household in $1974 .^{38}$

\section{United States Rule}

In the immediate period following the Second World War, the United States evicted the occupants of the Bonin Archipelago during its 
demilitarization of the area. A policy decision prohibiting the return of former civilian inhabitants was later changed to allow the descendants of the original colonists to resettle the war-torn archipelago. Islanders without this heritage, on the other hand, remained exiles until the United States Navy relinquished administrative control in 1968. This policy reduced a population of thousands to less than two hundred people. Canoes during the occupation period played a vital role since the chief industry was fishing. ${ }^{39}$ Islanders built their own canoes from indigenous materials and scrap metal courtesy of Uncle Sam. "Tin pot canoes," as they were called, were made from drop tanks, external auxiliary fuel tanks carried by aircraft that are designed to be jettisoned when expended. John Wick, a now retired eye surgeon who served as a medical officer on the islands from 1964 to 1966, remembers seeing two "tin pot canoes" during his time there. ${ }^{40}$ The Bonin islanders and American personnel attached to the naval facility obtained wooden outrigger canoes made by skilled craftsmen such as Seitarō Asanuma, a Bonin-born Japanese who resided in a city near Tokyo. ${ }^{41}$ Fiberglass canoes in use today, it has been reported, were molded from a wooden canoe (or canoes) introduced during this period. ${ }^{42}$

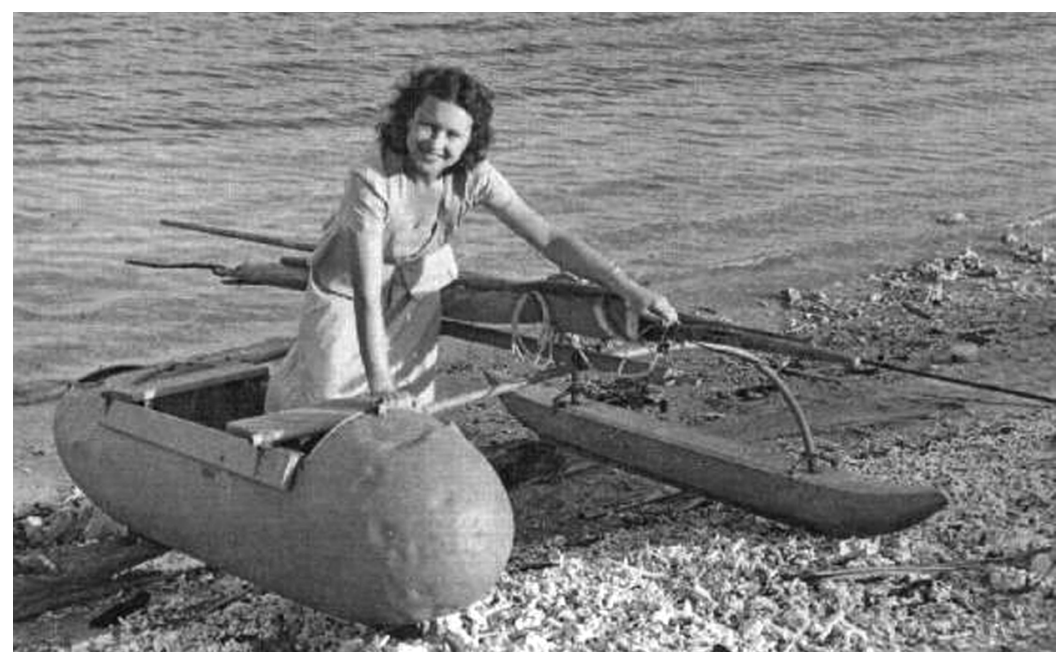

Figure 4. A photograph of Rose Pobst, a spouse of an American serviceman, posing with a Bonin "tin pot canoe." Courtesy of John Wick and the late Carol Pobst. 


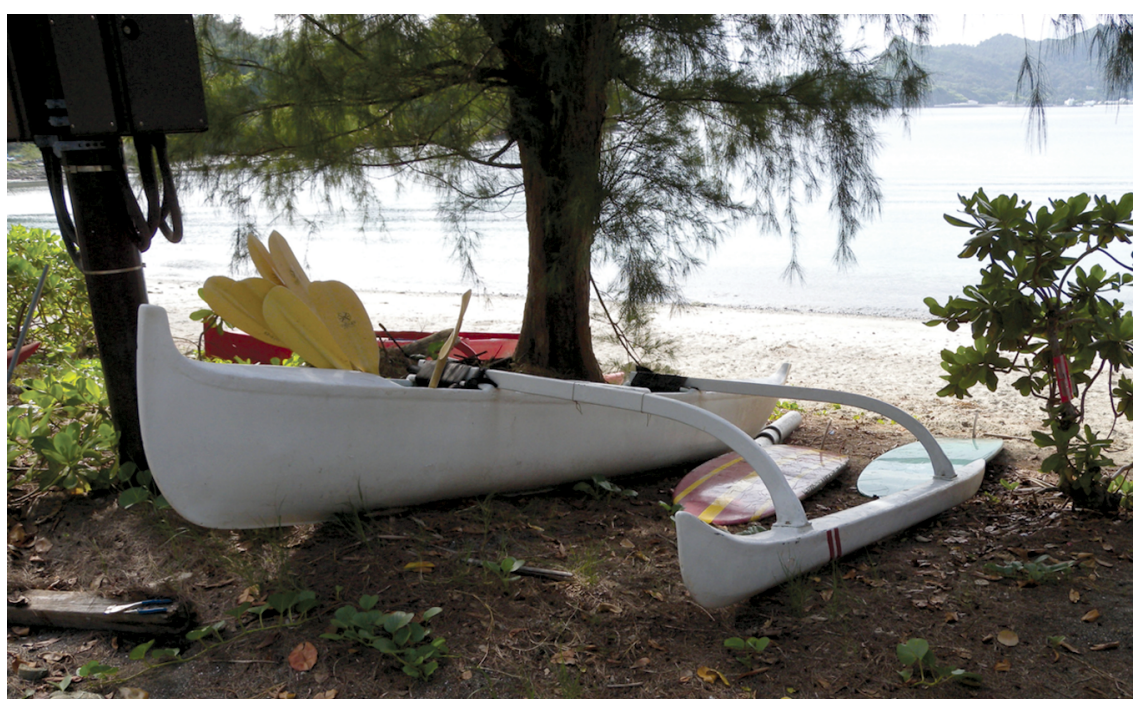

Figure 5. Photograph of an outrigger canoe in the Bonins, 2013.

The Americans provided the islanders with medical assistance, basic material needs, and access to Guam's fish market where catches could be sold for a decent price. ${ }^{43}$ Yankee technology and know-how were also a part of the arrangement. Every fisherman by $195^{8}$ owned at least one outboard motor, according to a U.S. naval report: "The canoes no longer return by tacking across the harbor with their picturesque sails spread and steering paddles flashing. Nor is it necessary to delay their return until fair tides and wind prevail." ${ }^{44}$ Sails now served as a backup for motors that ran out of gas or broke down. ${ }^{45}$ The image of the outrigger canoe with its wind-filled sail appealed to the Americans stationed on the Bonins, which is probably why it became a symbol for the local U.S. naval facility. The appealing image was placed on navy signs, documents, and knickknacks across the base (such as lighters, ashtrays, and patches) ${ }^{46}$

\section{Conclusion}

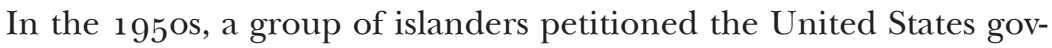
ernment to make the Bonin Archipelago an American territory. ${ }^{47}$ 
While the idea met with enthusiasm in some circles, Washington policymakers balked at the idea of stripping territory away from a Cold War ally. In 1968, the Bonins reverted back to Japanese rule and with it came profound changes. Tokyo was intent on modernizing the Bonins: its plans focused on developing infrastructure instead of preserving a unique regional culture. Japanese who relocated to the Bonins following reversion arrived with preconceived notions of island life that chafed local sensibilities. Over time, the dramatic demographic and cultural shifts reoriented the Bonin Archipelago. As a consequence of the handover and the archipelago's reintegration with the world at large, the importance of the outrigger canoe fell into decline. Today, its many contributions to the development of the archipelago go largely unremembered, and its impact upon local events is muted in popular narratives. The history of the Bonins would have been quite different without the outrigger canoe. This versatile watercraft was well-suited to the conditions of the archipelago, which is why it was an engine of the economy, a lifeline that connected the islands, and a constant part of the dramas of daily life. The outrigger canoe in the Bonin Archipelago is a success story and an example that the benefits of Hawaiian knowledge are not limited to life in the Hawaiian Islands.

\section{Notes}

* The authors would like to thank the people at Ogasawara Village's Board of Education, especially Ms. Kinuko Shimada whose assistance made this article possible.

${ }^{1}$ Bonin residents have used the loanword 'canoe' from before the annexation period, which has been written variously as kanō, kanū, kunō, and kunū. According to an American anthropologist who visited the Bonins in the 197os, outrigger canoes were called "pompoms." Mary Shepardson, "The Bonin Islands: Pawns of Power" (unpublished manuscript, 1998).

${ }^{2}$ Historians remain uncertain about the number of Hawaiians who settled the Bonins in 183 o. Due to the popularity of Rev. Cholmondeley's book with scholars and journalists, the number twenty-five is frequently offered. Lionel Berners Cholmondeley, The History of the Bonin Islands (London: Constable \& Co. Ltd., 1915) 17.

${ }^{3}$ Yamagata Ishinosuke, Ogasawaratō shi (Tokyo: Tōyōdō, 19o6) $5^{10 .}$

${ }^{4}$ Gotō Akira, Umi kara mita Nihonjin: Kaijin de yomu Nihon no rekishi (Tokyo: Kōdansha, 2010) 19-20. 
5 Tōkyō-fu Ogasawaratōchō, ed., Ogasawaratō shisan (1888) 262-263.

${ }^{6}$ Isomura Teikichi, Ogasawaratō yōran (Tokyo: Ben'ekisha, 1888) 267.

7 "Nakayoshi Maru hyōryūki," in Rikuzentakatashishi, ed. Rikuzentakatashishi Henshü Iinkai (Rikuzentakata: Rikuzentakatashi, 2002) 12: 201.

${ }^{8}$ Isomura, Ogasawaratō yōran 267.

${ }^{9}$ For a sketch of the 1840 canoe, see Scott Kramer and Hanae Kurihara Kramer, "The Other Islands of Aloha," HJH vol. 47 (2013): 14.

${ }^{10}$ Abe Rekisai, Zusho kōki (circa 1863). This report is housed in the National Diet Library of Japan.

11 Ogasawara mura sonsei yōran (Tokyo: Ogasawara mura, 2012) 22. The main transportation to the Bonins is the passenger ship Ogasawara Maru.

12 Willard Price, Japan's Islands of Mystery (New York: The John Day Company, 1944) 35-36; Yokoi Kōzō, Tōkyō kinkai shima no shasei kikōo (Tokyo: Hakubunkan, 1928) 376.

13 Samuel Jameson, "Navy's 'Mystery Base' in Bonins Irks Japanese," Chicago Tribune, 1 Nov. 1964 .

14 Timothy E. Head, co-author of the 1968 American Heritage article "The BoninsIsles of Contention," requested "a civilian travel permit to the Bonin Islands for the purpose of conducting historical research" in 1962. Like petitioners before him, he was denied access to the islands. His subsequent attempt proved equally unsuccessful. For Mr. Head's dealings with the US Navy, see Records of the Military Govt./Civil Affairs Branch of the Office of the CNO, Box 102, ser. VIII, subser. B. Operational Archives, Naval Historical Center, Washington D.C.

15 The Science Museum catalogued the item as "whole model of fishing canoe (outrigger) from Bonin Islands," inventory number: 1910-90.

${ }^{16}$ James Hornell, Canoes of Oceania, Volume I: The Canoes of Polynesia, Fiji, and Micronesia (Honolulu: BPBM, 1936) 28.

${ }^{17}$ Hornell, Canoes of Oceania 26-28. Absent in the above block quote are figure references (which are not needed here) and a citation to a previous work by the author, James Hornell. The text on figure 3 comes from the aforementioned work and the inset sketches have been inverted to bring out their detail.

${ }^{18}$ Hornell, Canoes of Oceania 28-29.

${ }^{19}$ Canoes from an earlier period lacked boom and float pegs altogether; makers relied solely on ropes and their skills to tie them.

${ }^{20}$ Color drawings of these masks are in Ogasawaratō shinkeizu, a handwritten manuscript housed in the Tokyo Metropolitan Archives.

${ }^{21}$ Kurata Yōji, Shashinchō Ogasawara (Kamakua: Abokkusha, 1983) 33; Gotō, Umi kara mita Nihonjin 14-16.

${ }^{22}$ Gotō, Umi kara mita Nihonjin ${ }_{15}$.

23 Ogasawaratō kiji shüi, vol. 5 (circa 1875). This document is housed in the National Archives of Japan.

24 The replica was made by a Sri Lankan craftsman who specialized in ceremonial masks. How this mask came to hang on the Ogasawara Village Tourist Association's wall is a bit of a mystery. The mask's attached explanation reads, "Mask to ward off evil spirits? People in the Bonin Archipelago-although in fewer 
numbers today than in years past-still use the outrigger canoe that was introduced to these islands by the original settlers from Hawai'i. In a document [Ogasawaratō shinkeizu] there is a picture of a bow mask [a mask that is affixed to the front of a canoe] with a scant description. Using the document's illustrations as a guide, this mask was made by a traditional Sri Lankan mask maker." The authors are grateful for the assistance provided by the Ogasawara Village Tourist Association, especially Ms. Kazue Oda.

${ }^{25}$ Furaidē Topoto is likely Friday, a man listed as a resident of the Bonins Islands just a few years prior to the incident. Russell Robertson, "The Bonin Islands," Transactions of the Asiatic Society of Japan vol. IV (1876): 131. The use of the term 'Kanaka' by the Japanese of the period meant Hawaiian in the narrow sense and more broadly anyone of Oceanian descent.

${ }^{26}$ Gaikoku kankei kasajima kiji, vol. 2 (1878-1879). Thomas Two-Crabs (also spelled Tewcrabs) and his son John are mentioned in the 25 August 1881 issue of The Japan Gazette on page 97.

27 "Deaths of Seamen," The Sailor's Magazine vol. 29, no. 9 (May 1857): 275.

28 Jenichiro Oyabe, A Japanese Robinson Crusoe (Boston: The Pilgrim Press, 1898) $71-75$.

29 "Dispatch from Mr. Robertson to Sir Harry S. Parks concerning the Bonin Islands," 44th Cong., 2 d sess., Ex. Doc. I, pt. I: Papers Relating to the Foreign Relations of the United States (Washington: Government Printing Office, 1876), 355-357. For additional information about Robertson's time on the islands, see Robertson, "The Bonin Islands" vol. IV, $111-142$.

30 "Dispatch from Mr. Robertson to Sir Harry S. Parks concerning the Bonin Islands" 355 .

${ }^{31}$ For two such accounts, see F. W. Beechey, Narrative of a Voyage to the Pacific and Beering's Strait (London: Henry Colburn \& Richard Bentley, 1831) 2: 231 and W. H. G. Kingston, The Three Admirals and the Adventures of Their Young Followers (London: Griffith and Farran, 1878) 18.

${ }^{32}$ Kondō Haruo, Ogasawara oyobi Hachijōjima ki (Tokyo: Tōyō Taimususha, 1917) $84-85$.

${ }^{33}$ Ishihara Shun, Kindai Nihon to Ogasawara shotō (Tokyo: Heibonsha, 2007) 286.

${ }^{34}$ Kondō, Ogasawara oyobi Hachijöjima ki 25-26, 87; Ishihara, Kindai Nihon to Ogasawara shotō 286.

35 Tōkyō-fu Ogasawaratō tōchō, Ogasawaratō tōsei ippan (Tokyo: Ogasawaratō tōchō, 1914) 123 .

36 Tōkyō-fu shomuka, Ogasawaratō nisshi (1884-1885).

37 Tōkyō-fu, Ogasawaratō sōran: Gyōkō hen (1929) 17, 57-59, 72-73.

${ }^{38}$ Hirohito, Emperor of Japan, Some Hydrozoans of the Bonin Islands (Tokyo: Biological Laboratory, Imperial Household, 1974).

${ }^{39}$ Dorothy Richard Pesce \& L. Gordon Findley, A History of the Bonin-Volcano Islands [Commander-in-Chief Pacific] 1958, US Navy declassified report, 26-29, 59-6o, 116. Even though the United States allowed the Öbeikei (descendants of the original colonists) to return, the complexities of the era ensured that many of them never saw a homecoming. 


\section{THE HAWAIIAN JOURNAL OF HISTORY}

${ }^{40}$ John Wick, personal communication, 25 Mar. 2014.

${ }^{41}$ Gotō, Umi kara mita Nihonjin 20.

42 Akira Goto, "Oceanic Encounter with the Japanese: An Outrigger Canoe-Fishing Gear Complex in the Bonin Islands and Hachijo-Jima Island," In Terra Australis 39: Prehistoric Marine Resource Use in the Indo-Pacific Regions, eds. Rintaro Ono, Alex Morrison, and David Addison (Canberra, Australia: Australian National University Press, 2013) 160.

${ }^{43}$ Pesce \& Findley, A History of the Bonin-Volcano Islands 11 $14^{-1} 18$.

${ }^{44}$ United States Pacific Fleet, Semi-Annual Report on the Bonin-Volcano Islands for the Period ending 3o June 1958. Records of the Military Govt./Civil Affairs Branch of the Office of the CNO, Box 97, ser. VIII, subser. A. Operational Archives, Naval Historical Center, Washington D.C.

${ }^{45}$ John Wick, personal communication, 25 Mar. 2014.

${ }_{46}$ These items sometime appear at flea markets, antique stores, and auctions.

${ }^{47}$ For a reprinted copy of "Request for United States Citizenship" with its list of signators, see Pesce \& Findley, A History of the Bonin-Volcano Islands 291. 